\title{
Pemodelan Karakteristik Pengeringan dan Analisis Perpindahan Panas pada Pengeringan Kentang (Solanum Tuberosum L.)
}

\author{
Devin Sitompul, Deviana Malinda, Salafudin \\ Program Studi Teknik Kimia, Itenas, Bandung, Indonesia \\ Email: salafudin@itenas.ac.id
}

Received 08 April $2021 \mid$ Revised 08 Juni 2021 | Accepted 10 Juni 2021

\begin{abstract}
ABSTRAK
Kentang merupakan salah satu jenis bahan makanan yang yang mempunyai kadar air tinggi. Karena itu kentang mudah rusak di suhu ruang dan menyebabkan kerugian yang besar sehingga dilakukan pengeringan. Penelitian ini untuk menentukan model karakteristik pengeringan secara empiris dan fundamental. Model karakteristik pengeringan digunakan untuk menjelaskan proses pengeringan pada bahan agar mengetahui nilai moisture ratio, analisis perpindahan panas dan dapat memodelkan ke jenis alat pengeringan lainnya. Pada penelitian ini hasil menunjukan model pengeringan lapis tipis midilli paling baik akurasinya dengan data eksperimen pengeringan Kentang (Solanum tuberosum L.). Adapun pada hasil analisis pemodelan secara fundamental dapat memodelkan ke jenis alat pengering lainnya pada kondisi yang sama pada data eksperimen yaitu dengan sistem closedloop dengan menggunakan adsorbent berupa silica gel. Pada pemodelan ini waktu yang dibutuhkan selama pengeringan lebih cepat dibandingkan dengan alat yang digunakan pada eksperimen dengan tray dryer.
\end{abstract}

Kata kunci: Pengeringan, Solanum tuberosum L., Model matematika pengeringan lapis tipis, sistem closedloop, adsorbent

\begin{abstract}
Potatoes are a type of food that has a high water content. Because of this, potatoes are easily damaged at room temperature and cause large losses so as to reduce the losses done drying. This study is to determine the model of drying characteristics empirically and fundamentally. The model of drying characteristics is used to explain the drying process in the material to know the moisture ratio value, heat transfer analysis and can model to other types of drying tools. In this study the results showed a thin layer drying midilli model best accuracy with data experiment drying Potato (Solanum tuberosum L.)As for the results of the modeling analysis are fundamentally able to model all kinds of other dryer on the same conditions on the experimental data, namely the system by using an adsorbent such closedloop silica gel. In this type of drying using adsorbent, the time required for drying is faster than the tool used in the experiment with the tray dryer.
\end{abstract}

Keywords: Drying, Solanum tuberosum L., Mathematical model of thin layer drying, closedloop system, adsorbent 


\section{PENDAHULUAN}

Perkembangan pemodelan dalam pengeringan terus berkembang hingga sekarang ini yang melibatkan proses-proses yang kompleks meliputi perpindahan massa, energi dan momentum. Pemodelan pengeringan dimulai dari sesuatu yang sederhana hingga kompleks yang semuanya dapat diterapkan sesuai dengan kondisi dan situasinya [1].

Aspek yang penting dari teknologi pengeringan adalah pemodelan dari proses pengeringan. Penggunaan model ini penting untuk memprediksi performasi sistem pengeringan. Tujuan pemodelan adalah untuk memudahkan dalam memilih kondisi operasi yang paling tepat dan kemudian dapat disesuaikan dengan kondisi operasi yang diinginkan. Adapun pemodelan proses pengeringan yang paling sederhana adalah model kinetika pengeringan untuk sistem pengeringan lapis tipis (thin layer drying). Model pengeringan tipe ini dapat dikategorikan sebagai sistem model parameter lump dimana konsentrasi air dan temperatur serta tebal bahan yang dikeringkan diasumsikan sama dan mempunyai karakteristik yang sama pula [2]. Karakteristik pengeringan untuk sistem ini dapat dinyatakan dengan konstanta pengeringan. Pemodelan pengeringan lapis tipis (thin layer drying) digunakan untuk memprediksi kurva pengeringan secara umum. Model matematika dan simulasi pengeringan dengan kondisi yang berbeda penting untuk memperoleh control yang lebih baik dalam unit operasi pengeringan dan perbaikan keseluruhan dari kualitas akhir produk [3].

Parameter-parameter model persamaan empiris ataupun konstanta yang dapat ditentukan melalui optimasi proses ataupun penentuan secara khusus sehingga diperoleh nilai-nilainya. Pada penentuan konstanta pengeringan berdasarkan pada model pengeringan lapis tipis yang berupa persamaan empiris dengan parameter yang akan ditentukan. Penentuan parameter-parameter ini dilakukan dengan pengkorelasi (curve fitting) terhadap data eksperimen dengan memanfaatkan teknik-teknik optimasi proses [4].

Selain pemodelan empiris dapat dilakukan dengan pemodelan secara fundamental untuk dapat memodelkan alat pada data eksperimen menjadi alat pengering yang lain sehingga dapat mengetahui waktu yang dibutuhkan serta energi yang diperlukan pada kondisi proses pengeringan yang sama. Dengan pemodelan secara fundamental dapat menentukan koefisien pengeringan, laju pengeringan pada pengeringan dengan alat yang berbeda, dan menentukan beberapa data yang tidak diketahui pada data eksperiment dengan menggunakan neraca massa serta energi pada proses pengeringan berlangsung.

Berkaitan dengan hal diatas maka akan dilakukan penelitian mengenai pemodelan matematika dengan menggunakan model lapisan tipis dan pemodelan secara fundamental dengan menggunakan data eskperimen pada bahan yang dikeringkan berupa pengeringan kentang sehingga dapat menganalisis jenis model yang paling baik antara pemodelan lapisan tipis dengan pemodelan secara fundamental.

\section{BAHAN DAN METODE}

\subsection{Bahan}

Kentang yang digunakan untuk pengeringan dalam penelitian dari Boutelba dkk (2018) merupakan kentang dengan varietas yang sama yang sebelum pengeringan dipotong dahulu dengan ketebalan 5,15 $\mathrm{mm}$, lebar $30,15 \mathrm{~mm}$ dan panjang $39.95 \mathrm{~mm}$. Proses pengeringan dilakukan secara koveksi pada pengering bertipe tray dryer dengan bantuan udara pengering dari blower. Kondisi dari udara pengering bersuhu $51{ }^{\circ} \mathrm{C}$, laju alir udara sebesar $1 \mathrm{~m} / \mathrm{s}$, dan RH sebesar 7,7\% [5].

\subsection{Pembentukan Model Empiris}

Berdasarkan data eksperimental digunakan untuk pemodelan lapisan tipis untuk kentang. Rasio kadar air atau Moisture Ratio dari eksperimen dapat dihitung dengan: 


$$
M R=\frac{M_{t}-M_{e}}{M_{o}-M_{e}}
$$

Dimana MR adalah bilangan tak berdimensi, $\mathrm{M}_{\mathrm{t}}$ adalah kadar air dari material di waktu $\mathrm{t}(\%$ dry basis), dan $\mathrm{M}_{\mathrm{o}}$ adalah kadar air saat awal (\% dry basis), dan $\mathrm{M}_{\mathrm{e}}$ adalah kesetimbangan kadar air dari bahan (\% dry basis) [6].

$$
M R=\frac{M_{t}}{M_{0}}
$$

MR dapat disederhanakan $k e M_{t} / M_{0}$ karena nilai dari $M_{e}$ sangat kecil dibandingkan nilai $M_{t}$ dan $M_{0}$ pada priode waktu yang lama [7]. Berikut model semi-teoritis yang digunakan dalam pemodelan lapisan tipis dalam penelitian ini:

Tabel 1. Model empiris untuk pengeringan[8]

\begin{tabular}{ccc}
\hline Nama Model & Model atau persamaan & Sumber \\
\hline Newton & MR $=\exp (-\mathrm{kt})$ & (O'Callaghan et al., 1971) \\
\hline Logarithmic & MR $=\mathrm{a} \exp (-\mathrm{kt})+\mathrm{c}$ & (Togrul and Pehlivan, 2002) \\
\hline Two-term model & $\mathrm{MR}=\mathrm{a} \exp (-\mathrm{k} \mathrm{t} \mathrm{t})+\mathrm{b} \exp \left(-\mathrm{k}_{1} \mathrm{t}\right)$ & (Henderson, 1974) \\
\hline Midilli & $\mathrm{MR}=\mathrm{a} \exp \left(-\mathrm{kt}^{\mathrm{n}}\right)+\mathrm{bt}$ & (Midilli et al., 2002) \\
\hline Model page & $\mathrm{MR}=\exp \left(-\mathrm{kt}^{\mathrm{n}}\right)$ & (page, 1974) \\
\hline
\end{tabular}

Nilai a, $\mathrm{k}, \mathrm{n}$, dan $\mathrm{c}$ adalah konstanta pengeringan yang akan ditentukan nilainya dengan metode regresi non-linear berdasarkan algoritma Lvenberg-Marquart dengan data eksperimental yang didapat dengan bantuan software solver dari microsoft excel.

\subsection{Analisis Model Empiris}

Analisa statistik dari data dilakukan dengan metode Regresi Non-linier berdasarkan algoritma lvenbergmarquart digunakan untuk memprediksi parameter sehingga dapat ditentukan model yang terbaik. Dalam penentuan model yang paling cocok digunakan beberapa parameter seperti Coefficient of determation (R2) dan Sum square error (SSE) dimana model yang paling cocok dinyatkaan dengan nilai R2 paling mendekati nilai 1 dan nilai SSE paling mendekati nilai 0 [9]. Parameter ini ditentukan dari persamaan berikut:

$$
\begin{gathered}
R^{2}=\frac{1-\left[\sum_{i=1}^{N}\left(M R_{\text {pre }, i}-M R_{\text {exp }, i}\right)^{2}\right]}{\left[\sum_{i=1}^{N}\left(\overline{M R}_{\text {pre }, i}-M R_{\text {exp }, i}\right)^{2}\right]} \\
S S E=\left[\frac{\sum_{i=1}^{N}\left(M R_{\text {pre }, i}-M R_{\text {exp }, i}\right)^{2}}{N}\right]
\end{gathered}
$$

Dimana $\mathrm{MR}_{\text {exp,i }}$ merupakan MR eksperimen pada waktu i, $\mathrm{MR}_{\text {pre, }}$ merupakan MR Prediksi pada waktu $\mathrm{I}$, dan $\mathrm{N}$ merupakan jumlah sampel.

\subsection{Pembentukan Pemodelan Fundamental}

Dalam membentuk model secara fundamental berdasarkan nilai koefisien perpindahan massa pengeringan (ky) menggunakan asumsi bahwa suhu dan kadar air pada kentang seragam dan model dibentuk dengan kondisi suhu di drying chamber sama. Ada 3 model yang akan di bentuk yaitu Pengeringan Tray dryer secara eksperimen bila dilakukan di Indonesia, Pengeringan dengan Adsorbent Silica Gel secara Closeloop, dan optimasi Pengeringan dengan Adsorbent Silica Gel secara Closeloop. 
Untuk menentukan koefisien perpindahan massa pengeringan (ky) diperlukan nilai kelembapan absolut dipermukaan bahan $\left(\mathrm{Y}^{*}\right)$ dan kelembapan absolut udara pengering $(\mathrm{Y})[10]$.

$$
N=k y\left(Y^{*}-Y\right)
$$

Dan untuk mencari nilai laju pengeringan $(\mathrm{N})$ menggunakan persamaan 6, dimana $\mathrm{W}_{\mathrm{k}}$ merupakan berat kering bahan, A merupakan luas permukaan bahan, $\mathrm{x}$ kadar air bahan, dan $\mathrm{t}$ adalah waktu pengeringan [4].

$$
N=\frac{-W_{k}}{A} \frac{d x}{d t}
$$

\subsection{Pembentukan Model Pengeringan Kentang Bila Dilakukan Di Indonesia}

Asumsi untuk menghitung neraca massa dan panas, sistem pengeringan dibagi ke beberapa bagian, dan dihitung berdasarkan perpindahan massa dan entalpinya. Asumsi yang digunakan yaitu tidak ada panas hilang dari tiap alat, physical properties yang digunakan tidak berubah selama pengeringan, tekanan operasi $1 \mathrm{~atm}$ dan pressure drop dianggap tidak ada, kadar air dan suhu pada bahan seragam, dan relative humidity pada udara ruang sebesar $80 \%$ pada suhu $27{ }^{\circ} \mathrm{C}$. Bentuk skema alat percobaan ini dapat dilihat dari Gambar 1.

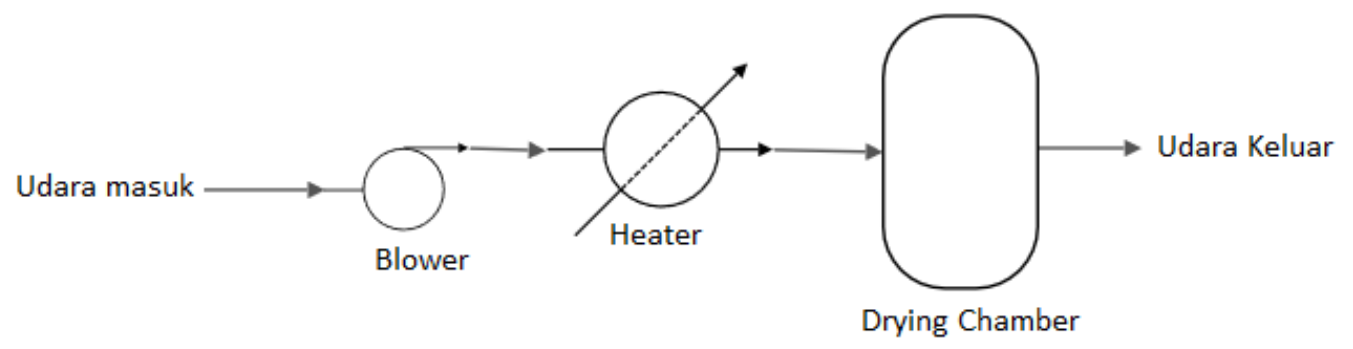

Gambar 1. Skema alat pada pemodelan pengeringan kentang

\subsection{Pembentukan Model Pengeringan Closeloop Kentang Dengan Adsorbent}

Pembentukan model dilakukan secara closeloop menggunakan adsorbent silica gel dan juga dimodelkan secara optimasi dengan penambahan alat Heat Exchanger. Dalam percobaan pengeringan closeloop, udara pengering mulai disirkulasikan pada menit ke-1. Bentuk skema alat percobaan secara closeloop dapat dilihat di Gambar 2 dan yang dioptimasi pada Gambar 3.

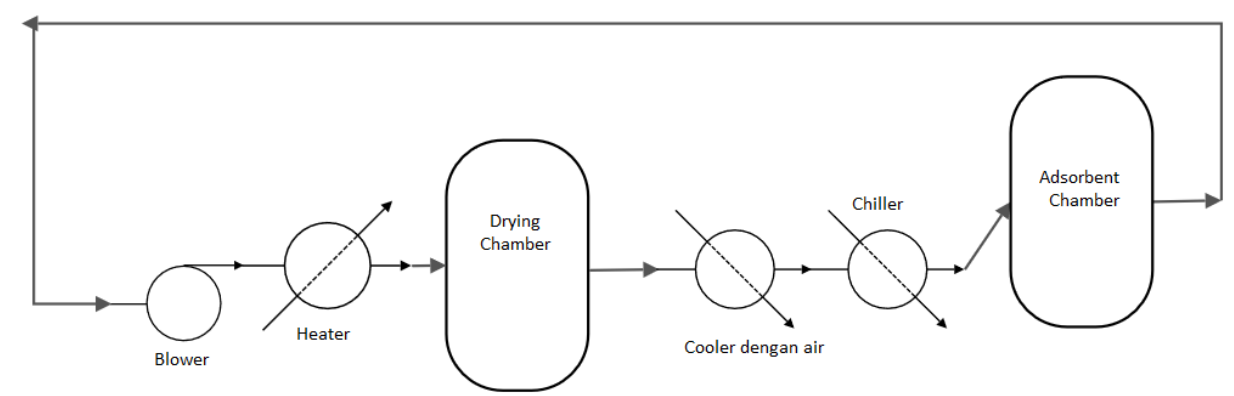

Gambar 2. Skema alat pada pemodelan pengeringan secara closeloop 


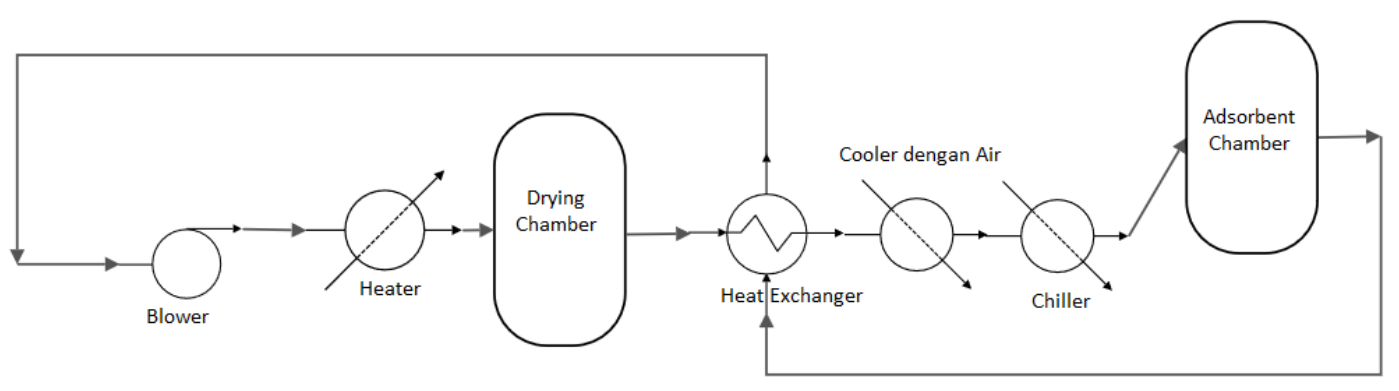

Gambar 3. Skema alat pada pemodelan pengeringan optimasi secara closeloop

\section{HASIL DAN PEMBAHASAN}

Pada penelitian ini dilakukan dengan menggunakan data eksperimen pada pengeringan kentang, dengan menyusun persamaan model matematika pengeringan lapisan tipis untuk mendapatkan model matematika yang terbaik dengan akurasinya yang mendekati dengan data ekperimen pengeringannya. Pada model matematika pengeringan lapisan tipis ini dihitung berdasarkan data MR dari data eksperimen. Dalam analisa regresi linier dan non linier dapat diselesaikan dengan menggunakan program MS excel solver. Dengan mengunakan analisa solver akan secara otomatis mencari nilai konstanta yang ada pada model yang digunakan. Adapun kriteria utama yang digunakan untuk memilih model terbaik adalah dengan menetapkan nilai tertinggi dari koefisien determinasi (R2) serta nilai terendah dari Sum Square Error (SSE).

Data eksperimen pada pengeringan kentang ini dengan alat pengering berupa tray dryer dapat dilakukan pemodelan secara fundamental untuk memodelkan proses pengeringan kentang pada sistem closedloop sehingga dapat diperoleh besarnya energi serta waktu yang dibutuhkan pada proses pengeringan kentang. Dalam proses pengeringan ini ada perpindahan massa air dari bahan yang dikeringkan ke media pengering. Transfer massa ini ditandai dengan pengurangan massa bahan, pada proses perpindahan massa ini dipengaruhi juga oleh transfer panas. Transfer panas ini dipengaruhi oleh perubahan suhu pengering serta perubahan laju alir udara pengering.

\subsection{Perbandingan Antara Data Eksperimen Pengeringan Kentang dengan Prediksi Model Matematika}

Diperoleh pada Tabel 2 untuk model pengeringan berdasarkan analisa regresi non-linear menggunakan software excel solver. Tingkat akurasi dan ketelitian setiap model pengeringan dalam mengestimasi data percobaan pengeringan kentang di evaluasi menggunakan parameter uji statistik yaitu koefisien determinasi $\left(\mathrm{R}^{2}\right.$ ), dan Sum Square Error (SSE). Nilai $\mathrm{R}^{2}$ adalah indikator akurasi bentuk kurva model pengeringan dalam mengikuti karakteristik bentuk kurva data hasil eksperimen pengeringan.

Tabel 2. Tabel analisa statistik model pengeringan lapisan tipis

\begin{tabular}{ccrc}
\hline Nama Model & Konstanta dan koefisien & $\mathrm{R} 2$ & $\mathrm{SSE}$ \\
\hline Newton & $\mathrm{k}=0,0107$ & 0,9982 & 0,0053 \\
\hline Page & $\mathrm{k}=0,0056 ; \mathrm{n}=1,1361$ & 0,9995 & 0,0006 \\
\hline Logarithmic & $\mathrm{a}=0,9999 ; \mathrm{k}=0,0107 ; \mathrm{c}=-2,1543 \times 10^{-6}$ & 0,9982 & $2,1 \times 10^{-11}$ \\
\hline Two-Term & $\mathrm{a}=0,2751 ; \mathrm{b}=0,7506 ; \mathrm{k}_{0}=0,0110 ; \mathrm{k}_{1}=0,0110$ & 0,9975 & 0,0044 \\
\hline Midilli & $\mathrm{a}=0,9990 ; \mathrm{b}=-3,4680 \times 10^{-5} ; \mathrm{k}=0,0063 ; \mathrm{n}=1,1075$ & 0,9998 & 0,0003 \\
\hline
\end{tabular}

Untuk nilai SSE merupakan deviasi antara nilai prediksi dengan data eksperimen pengeringan kentang. Sebuah model pengeringan dikategorikan paling akurat memprediksi data percobaan jika mempunyai nilai $\mathrm{R}^{2}$ besar dan didapatkan nilai SSE terkecil. Pada data yang diperoleh nilai $\mathrm{R}^{2}$ pada lima model pengeringan didapatkan nilai $\mathrm{R}$ berkisar $(0,9975$ - 0,9998) hal ini menunjukan bahwa kelima model tersebut dapat dikatakan tingkat akurasi dan ketelitiannya baik. Dari kelima model tersebut model yang 
paling baik akurasinya dengan data eksperimen yaitu model midilli dikarenakan didapatkan nilai $\mathrm{R}^{2}$ lebih besar diantara model yang lainnya, artinya model midilli cukup representatif untuk pengeringan kentang.

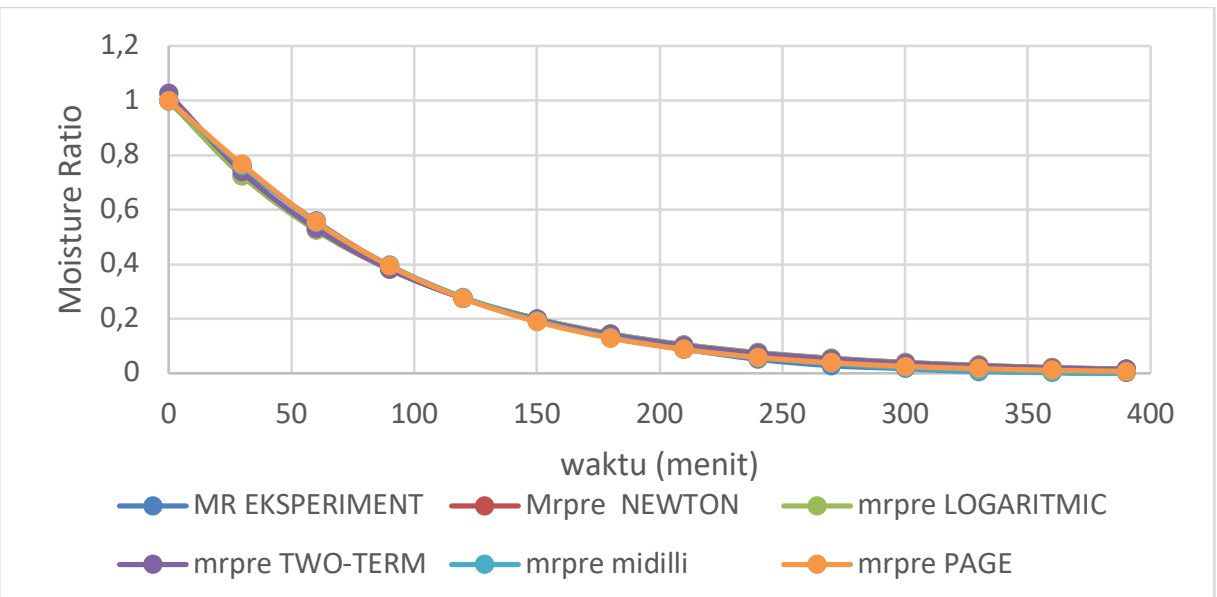

\section{Gambar 4. Perbandingan antara Moisture Ratio (MR) hasil prediksi dengan hasil eksperimen terhadap waktu}

Perbandingan antara moisture ratio (MR) hasil prediksi dengan hasil eksperimen dapat disajikan pada Gambar 4. Dari gambar ini dapat dilihat bahwa terdapat kesesuaian yang cukup baik antara moisture ratio hasil eksperimen dengan moisture hasil prediksi dalam lima model pengeringan.

\subsection{Menentukan Koefisien Pengeringan (ky) Pada Kentang}

Grafik pada Gambar 5 menunjukkan bahwa semakin lama waktu maka koefisien pengeringan yang diperoleh semakin berkurang. Nilai koefisien pengeringan ini digunakan untuk memperkirakan waktu yang dibutuhkan untuk mencapai kadar air tertentu. Pada data yang diperoleh bahwa koefisien pengeringan terhadap waktu dengan menggunakan tray dan pemodelan adsorbent dengan closedloop serta adsorbent closedloop dengan optimasi didapatkan nilai koefisien pengeringan yang berbeda. Hal ini dikarenakan perbedaan driving force berupa selisih Absolute Humidity pada udara pengering di pengeringan closeloop lebih besar sehingga nilai koefisien terhadap waktu beda.

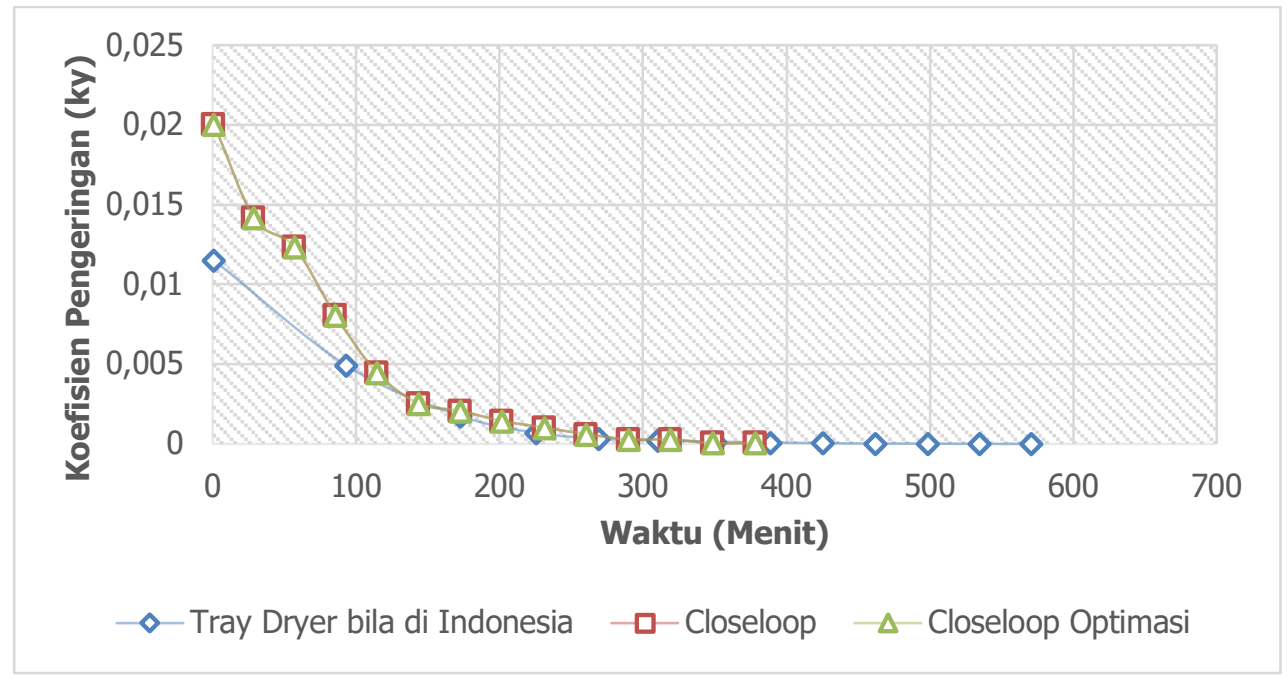

Gambar 5. Hubungan koefiesien pengeringan terhadap waktu 


\subsection{Laju Pengeringan Pada Kentang}

Pada Gambar 6 diperoleh data hubungan antara laju pengeringan terhadap x (Moisture Content Dry Basis) dimana semakin besar nilai x maka laju pengeringan semakin meningkat. Hal ini dikarenakan pada proses awal pengeringan kandungan air bebas pada bahan masih tinggi dan mudah diuapkan sedangkan pada akhir pengeringan kandungan air sudah mulai sulit dilepaskan karena kadar air bahan terikat. Dimana tekanan uap air dari air terikat akan lebih rendah dibandingkan tekanan uap air bebas pada suhu yang sama.

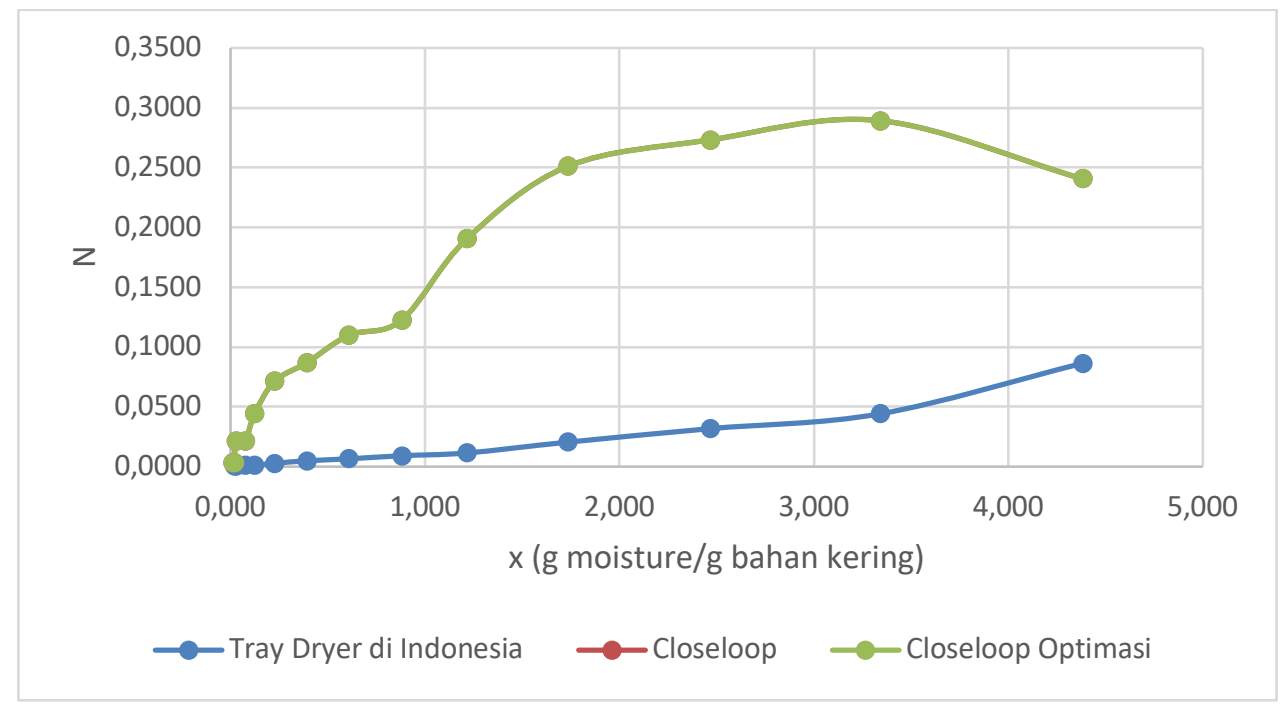

Gambar 6. Hubungan laju pengeringan (N) dengan $x$

\subsection{Menentukan Jumlah Waktu Yang Dibutuhkan Pada Proses Pengeringan}

Pada data eksperimen menggunakan alat berupa tray membutuhkan waktu 390 menit. Setelah melakukan pemodelan pengeringan bila dilakukan di Indonesia didapatkan waktu pengeringan 607,35 menit lalu dilakukan pemodelan proses pengeringan kentang secara closedloop dan didapatkan waktu sebesar 378,24 menit. Dalam hal ini waktu yang dibutuhkan untuk mengeringkan kentang pada suhu yang sama dengan menggunakan pemodelan dibuatkan pengeringan secara closedloop waktu yang dibutuhkan relatif lebih cepat. Hal ini dikarenakan pada sistem closedloop menggunakan adsorbent berupa silica gel. Pada sistem ini udara sebagai media pengering diturunkan dahulu kelembabannya (kadar airnya) dengan diserap oleh silica gel yang telah diaktifasi. Dengan rendahnya kadar air maka udara mampu menguapkan air pada bahan lebih besar dibandingkan dengan menggunakan tray. Dengan demikian maka dalam menguapkan air pada bahan akan membutuhkan waktu pengeringan yang lebih cepat.

Tabel 3. Waktu yang dibutuhkan pada tiap model pengeringan

\begin{tabular}{cc}
\hline Jenis Model & Waktu Pengeringan (menit) \\
\hline Model Pengeringan Tray Dryer di Indonesia & 607,35 \\
\hline Model Pengeringan Closeloop & 378,24 \\
\hline Model Pengeringan Closeloop di Optimasi & 378,24 \\
\hline
\end{tabular}

\subsection{Analisis Energi dan Ekonomi Dari Tiap Pemodelan Kentang}

Dari hasil perhitungan neraca massa dan energi dari seluruh proses pengeringan berlangsung maka akan didapatkan kebutuhan energi yang dibutuhkan selama proses pengeringan berlangsung dapat dilihat di Tabel 4. 
Tabel 4. Waktu yang dibutuhkan pada tiap model pengeringan

\begin{tabular}{|c|c|c|c|c|c|}
\hline \multirow{2}{*}{ Jenis Model } & \multirow{2}{*}{$\begin{array}{c}\text { Heater } \\
\text { Qhe }(\mathrm{kJ})\end{array}$} & \multirow{2}{*}{$\begin{array}{c}\text { Regenerasi } \\
\text { Qreg }(\mathrm{kJ})\end{array}$} & \multicolumn{2}{|c|}{ Pendingin } & \multirow{2}{*}{ Total $(\mathrm{kJ})$} \\
\hline & & & $\mathrm{Q}_{\mathrm{co}}(\mathrm{kJ})$ & $\mathrm{Q}_{\mathrm{ch}}(\mathrm{kJ})$ & \\
\hline Model Pengeringan Tray Dryer di Indonesia & 1254,4 & - & - & - & 1254,4 \\
\hline Model Pengeringan Closeloop & 743,0 & 71,6 & 344,4 & 406,5 & 1565,5 \\
\hline Model Pengeringan Closeloop di Optimasi & 447,6 & 71,6 & 44,7 & 406,5 & 970,4 \\
\hline
\end{tabular}

Proses pengeringan kentang yang dimodelkan dengan sistem closedloop yang dioptimasi didapatkan total energi yang dibutuhkan menurun sebesar 20\% dibandingkan dengan energi yang dibutuhkan oleh tray dryer di Indonesia. Pada sistem closedloop adsorbent perlu diregenerasi, dimana regenerasi dilakukan secara batch setelah pengeringan dilakukan, pada regenerasi ini membutuhkan energi sebesar 71,6 kJ. Pada sistem closedloop juga dilakukan pendinginan sebelum masuk ke adsorbent chamber sebesar dengan menggunakan Chiller (Qch) dimana sebelumnya dilewatkan dahulu ke pendinginan dengan air untuk mengurangi beban pendinginan.

Pada energi yang dibutuhkan oleh heater di pengeringan tray dryer dibutuhkan energi yang lebih besar karena energi digunakan untuk memanaskan udara pengering lebih banyak karena prosesnya jauh lebih lama, pada pengeringan closeloop energi yang dibutuhkan lebih kecil karena udara umpan merupakan udara keluar dari adsorbent yang disirkulasikan serta pengaruh lama pengeringan yang lebih cepat, dan pada pengeringan closeloop optimasi didapatkan energi lebih kecil lagi karena dilakukan integrasi panas dengan alat penukar panas sehingga beban energi untuk pendingin dengan cooler menjadi lebih kecil.

Tabel 5. Biaya selama proses pada tiap model pengeringan

\begin{tabular}{ccccccc}
\hline Jenis Model & Heater & Regenerasi & Cooler & Chiller & Blower & Total Harga \\
\hline $\begin{array}{c}\text { Model Pengeringan Tray } \\
\text { Dryer di Indonesia }\end{array}$ & $\mathrm{Rp} 15.727,12$ & - & - & - & $\mathrm{Rp} 838,78$ & $\mathrm{Rp} 16.565,90$ \\
\hline $\begin{array}{c}\text { Model Pengeringan } \\
\text { Closeloop }\end{array}$ & $\mathrm{Rp} 9.794,26$ & $\mathrm{Rp} 2.485,87$ & $\mathrm{Rp} 84,88$ & $\mathrm{Rp} 652,95$ & $\mathrm{Rp} 522,36$ & $\mathrm{Rp} 13.540,33$ \\
\hline $\begin{array}{c}\text { Model Pengeringan } \\
\text { Closeloop di Optimasi }\end{array}$ & $\mathrm{Rp} 9.794,26$ & $\mathrm{Rp} 2.485,87$ & $\mathrm{Rp} 84,88$ & $\mathrm{Rp} 652,95$ & $\mathrm{Rp} 522,36$ & $\mathrm{Rp} 13.540,33$ \\
\hline
\end{tabular}

Analisis ekonomi dari tiap kebutuhan panas dari tiap alat lalu dianalisis jumlah biaya saat proses berjalan. Model pengeringan secara closeloop dan Model pengeringan yang dioptimasi didapatkan harga lebih murah yaitu sebesar Rp. 13.540,33 dibandingkan model pengeringan di Indonesia sebesar Rp. 16.565,90. Namun Model Pengeringan secara closeloop akan membutuhkan biaya investasi alat yang lebih besar karena membutuhkan alat tambahan seperti cooler, chiller, dan alat penukar panas. Adapun yang menyebabkan perbedaan biaya proses dengan model closedloop lebih murah dibandingkan dengan model tray dryer di Indonesia karena waktu yang dibutuhkan selama proses pengeringan dengan target hasil yang sama jauh lebih cepat dengan model closedloop yaitu sebesar 6 jam.

\subsection{Perbandingan Pemodelan Empiris Dan Pemodelan Secara Fundamental}

Pada penggunaaan pemodelan matematika secara empiris terbatas hanya dapat menghitung Moisture Ratio (MR) untuk menggambarkan karakteristik pengeringan kentang pada eksperimen. Sedangkan jika menggunakan pemodelan secara fundamental dapat memodelkan data eksperimen dengan alat tray dryer menjadi alat lain yaitu alat pengeringan dengan adsorbent dengan closedloop, dimana driving force berupa absolute humidity dapat diubah untuk mempercepat waktu pengeringan dan dapt membandingkan kebutuhan energi dari tiap model proses pengeringan.

Jadi dengan menggunakan pemodelan fundamental dapat diaplikasikan untuk memodelkan ke jenis alat yang lainnya dengan kondisi yang sama sedangkan secara empiris terbatas hanya dapat menunjukan perpindahan massa airnya pada proses pengeringan yang dilakukan pada tray dryer dengan kondisi 
proses yang sama saja sehingga tidak dapat diaplikasikan ke dalam jenis alat yang lainnya ataupun suhu yang berbeda.

\section{KESIMPULAN}

Dari hasil penelitian yang telah dilakukan dapat disimpulkan, Model matematika lapis tipis untuk memprediksi pengeringan untuk kentang didapatkan model Midilli yang paling baik, nilai koefisien pengeringan seiring waktu akan menurun nilainya karena kadar air dalam bahan akan terus berkurang, pengeringan kentang secara closedloop membutuhkan waktu pengeringan lebih cepat, optimasi pada pengeringan closeloop dapat menurunkan kebutuhan energi sebanyak $20 \%$ dan mempercepat proses pengeringan 4 jam lebih cepat, dan pemodelan secara fundamental lebih dapat diaplikasikan ke jenis pengeringan lain sedangkan secara empiris hanya berlaku pada kondisi yang sama dengan eksperimen.

\section{DAFTAR PUSTAKA}

[1] Kurniawan, H., Septiyana, K. R., Adnand, M., Adriansyah, I., \& Nurkayanti, H. (2020). Karakteristik Pengeringan Gula Semut Menggunakan Alat Pengering Silinder Tipe Rak. Rona Teknik Pertanian, 13(2), 1-13.

[2] Kumar, D., Tarafdar, A., Kumar, Y., \& Badgujar, P. C. (2019). Intelligent modeling and detailed analysis of drying, hydration, thermal, and spectral characteristics for convective drying of chicken breast slices. Journal of Food Process Engineering, 42(5). doi:10.1111/jfpe.13087

[3] Permatasari, O. D. (2019). Karakteristik Pengeringan Rebung Petung (Dendrocallamus Asper) Di Bawah Paparan Gelombang Mikro (Doctoral dissertation, Fakultas Teknologi Pertanian Universitas Jember)

[4] Taufan, A., Karim, M. A., Novrinaldi, N., Putra, S. A., Haryanto, A., Pramono, E. K., \& Hanifah, U. (2020). Studi Eksperimental Dan Model Matematika Pengeringan Daun Kelor (Moringa Oleifera) Dengan Empat Tipe Pengeringan (Experimental Study And Mathematical Model Of Moringa Oleifera Leaves Drying With Four Drying Types). Jurnal Riset Teknologi Industri, 14(2), 341-352.

[5] Boutelba, S.Zid, P.Glouannec, A. Magueresse and S. Youcef-ali. (2018). Experimental data on convective drying of potato samples with different thickness. Volume 18, Pages 1567-1575. Dipetik September 8, 2020, dari Sciencedirect.com: https://doi.org/10.1016/j.dib.2018.04.065

[6] Kipcak, A. S., \& Ismail, O. (2018).Comparison of the microwave drying kinetics of culture and natural asparagus. Acta Scientiarum. Technology, 40, e39922-e39922.

[7] Abou, M. M. N., Madougou, S., \& Boukar, M. (2019). Effect of Drying Air Velocity on Drying Kinetics of Tomato Slices in a Forced-Convective Solar Tunnel Dryer. Journal of Sustainable Bioenergy Systems, 9(02), 64.

[8] Jia, Z., Liu, B., Li, C., Fang, T., \& Chen, J. (2018). Newly designed superheated steam dryer bearing heat recovery unit: Analysis of energy efficiency and kinetics of Kelp drying. Drying Technology, 36(13), 1619-1630. doi:10.1080/07373937.2017.1420080

[9] Alara, O. R., Abdurahman, N. H., \& Olalere, O. A. (2019). Mathematical modelling and morphological properties of thin layer oven drying of Vernonia amygdalina leaves. Journal of the Saudi Society of Agricultural Sciences, 18(3), 309-315.

[10] Hariyadi, T. (2018). Pengaruh Suhu Operasi terhadap Penentuan Karakteristik Pengeringan Busa Sari Buah Tomat Menggunakan Tray Dryer. Jurnal Rekayasa Proses, 12(2), 104-113. 